\title{
Morphological, physiological, pests and diseases responses of citrus seedling cultivars, and their contribution to cultivar classification under nursery house and open field
}

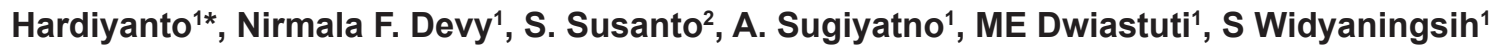 \\ ${ }^{1}$ Indonesian Citrus and Subtropical Fruits Research Institute, Jln. Raya Tlekung No. 1, Junrejo, Batu, East Java, Indonesia. 65301, ${ }^{2 B}$ Bogor \\ University. Darmaga Kampus Bogor. Jl. Baranang Siang No., Bogor, West Java, Indonesia
}

\section{A B S T R A C T}

Information of morphological, physiological, and pests and diseases traits between Siam or Tangerine (C. nobilis L.) and Keprok or Mandarin (C. sinensis) seedlings group under nursery and open filed condition in Indonesia has limited. The contribution of morphological and physiological characters to cultivar classification of Siam and Mandarin group has also not been yet documented. The aims of this research were to evaluate the morphological, physiological, pests and diseases responses of citrus seedling cultivars, and their contribution to cultivar classification. This research was conducted at Tlekung Experimental Garden, Citrus and Subtropical Fruits Research Institute, Batu, East Java, Indonesia from February to December 2020. One-year-old budded seedlings were planted in plastic bags (size $15 \times 30 \mathrm{~cm}$ ) and put in both a nursery house and open field. The plastic bags were filled with mixed media (rice hull, soil, and compost) with the ratio of 1:1:1. The experimental design was a Two Stage Nested Design consisted of two factors, these were factor A: locations (nursery house and open field) and factor B as a nested-on factor A: cultivars (Siam cv. Pontianak, Siam cv. Banjar, Siam cv. Madu, Keprok cv. Kacang, Keprok cv. Terigas, Keprok cv. Madura and Keprok cv. Gayo). The results showed that the highest flush growth percentage was showed by Keprok cv. Madura grown under open field condition, while the biggest rootstock diameter was obtained from Siam cv. Madu grown in nursery house. Siam cv. Madu grown in open field also produced the highest root dry weight and stomata density. In terms of pests and diseases, aphids (Aphis gossypii) and leaf miner (Phyllocnistis citrella) have only been affected by locations, while for diseases was not found in this study. Contribution of morphological and physiological traits to citrus cultivars classification were about $64.70 \%$. The average percentage of change in growth and develop capacity of Keprok group from open field to the nursery house increased by $2.35 \%$, whereas for Siam one tended to decrease by $8.96 \%$. In general, responses of morphological and/or physiological traits between Siam and mandarin group two locations were varied. Morphological and physiological traits may also useful for supporting genetically evaluation in improving citrus breeding programs.

Keywords: Citrus; Cultivar; Keprok; Mandarin; Siam; Tangerine

\section{INTRODUCTION}

Citrus is one of major horticultural crop in Indonesia that it has been cultivated over 55.000 ha in almost all Provinces, with total production is about 2.5 million ton. Since 1990, virus free citrus seedlings have been produced and commercially distributed. Producing the commercial citrus seedlings in the screen or nursery house is recommended, nevertheless, many growers in several provinces have still produced citrus seedlings in open fields that may affect the quality of seedlings. Good cultural practices application such as irrigation, fertilizer application, and pest and diseases control for obtaining qualified citrus seedlings either under screen house or in open field has to be considered (Barreto et al., 2015; Handl, 2016; Mattos Jr et al., 2017; Li et al., 2019; Ortas and Ustuner, 2014).

The success of citrus agribusiness depends on the quality of the seedlings used and where they are produced. Most of the good farmers and/or growers select the best seedlings from morphological characters such as vigorous, large, and healthy. Perumal et al. (2019) stated that evaluation of

\footnotetext{
*Corresponding author:

Hardiyanto, Indonesian Citrus and Subtropical Fruits Research Institute, JIn. Raya Tlekung No. 1, Junrejo, Batu, East Java, Indonesia.65301. E-mail: hardiyanto85@yahoo.com
} 
both morphological and physiological traits of seedlings in nursery house is absolutely needed to provide qualified seedling logistic prior to distribute and cultivate in the field. In terms of morphological and physiological traits, Haase (2008) also mentioned that shoot height, root diameter, shoot and root biomass, and shoot/root ratio are commonly used as a guidance for determining seedling quality in nursery and estimating when these seedlings are ready to be transplanted. Hence, it needs data on the selection of quality seed production and superior cultivars to get healthy plants that can grow and develop optimally in the field (Takoutsing et al., 2014).

Many scientists have reported the effect nursery house as well as shading with various treatments in many crops such as oil palm (Akpo et al., 2014), avocado (Tinyane and Sivakumar, 2018); sub-tropical fruits (Mditshwa et al., 2019); and forest trees (Nyoka et al., 2018). According to Mahmood et al. (2018), producing seedling plants under shading may reduce the sunlight intensity, air temperature and evapotranspiration, also increase air relative humidity for about $15-39 \%, 2.3-2.5 \%, 17-50 \%$, and $2-21 \%$, respectively. Nevertheless, this condition is also influenced by shading and net model, climatic condition, crops and cultivars. García-sánchez et al. (2015) also reported that setting up of shading (50\% aluminet) would induce the vegetative growth of lime seedlings and shorting time for transplanting. This condition also gave a positive impact on physiological response such as increase in photosynthetic rate $(13 \%)$, stomatal conductance $(8 \%)$ and water use efficiency $(14 \%)$ as well as chlorophyll b by $23 \%$. In terms of 'Lane Late' Navel oranges leaves number, it would be higher when under the aluminet (50\%) and black shade nets $(75 \%)$ conditions than control as well as the red leno $(20 \%)$ and clear nets $(13 \%)$. The same trend was also showed by the PSII and its chlorophyll content of 'Lane Late' Navel Orange (Incesu et al., 2016).

In terms of citrus cultivar classification, many commercially citrus species as well as cultivars have established in Indonesia such as groups of "Keprok" as known as Mandarin (C. reticulata) such as Madura, Kacang, Terigas, and Gayo; "Siam" as known as Tangerine (C. nobilis L.) such as Pontianak, Banjar, and Madu; Sweet Oranges (C. sinensis) such as Pacitan and Valencia; and Pummelo (C. maxima Merr.) such as Magetan, Sri Nyonya, and Magetan. "Terigas" may derive from natural hybridization between Siam and Mandarin, and most of farmers mentioned that Terigas belongs to Keprok/Mandarin group. In terms of Tangerine/Siam, Siam Pontianak and Banjar are mostly established in West and South Kalimantan, respectively; since Siam Madu originates from North Sumatera. In addition, within cultivars the morphological or genetically characters vary, so do their performance in the field (Agisimanto et al., 2007; Martasari, 2012; Devy and Hardiyanto, 2017). Based on the genetic similarity, it seems that their parent came from the same region. Specific attributes of both morphological and physiological traits in each cluster are very useful for citrus improvement programs. Moreover, by combining genetic and phenology variations in cultivar classification could more efficiently evaluate the variations among citrus accessions for breeding programs. However, information on the contribution of morphological and physiological traits to citrus cultivar classification especially between Siam and mandarin group has limited.

The aims of this research were to identify the morphological and physiological response of tangerine and mandarin citrus seedling groups, existence of pest and diseases, and to determine their contribution to citrus classification.

\section{MATERIAL AND METHODS}

\section{Site and time of research}

This research was conducted at Tlekung Experimental Garden, Indonesian Citrus and Subtropical Fruits Research Institute (ICISFRI), Batu-East Java, Indonesia from February to December 2020. The elevation of this place is $\pm 950 \mathrm{~m}$ above sea level.

\section{Experimental design}

This study was arranged in a Two Stage Nested Design consisted of 2 factors these were factor A: locations (nursery house and open field) and factor B as a nested-on factor A (seven citrus cultivars). Two types of citrus species were used in this study, there were Siam (S) or Tangerine (Siam cv. Pontianak, Siam cv. Banjar, Siam cv. Madu), and Keprok (K) or Mandarin (Keprok cv. Madura, Keprok cv. Kacang, Keprok cv. Terigas, and Keprok cv. Gayo). All plants were budded onto Japanese Citrus (JC) rootstock. These one-year-old budded seedlings were planted in plastic bags (size $15 \times 30 \mathrm{~cm}$ ) and put in both a nursery house and open field. The plastic bags were filled with mixed media (rice hull, soil, and compost) with the ratio of 1:1:1. Every polybag-citrus seedling was fertilized with 10 grams of $\mathrm{NPK}+$ ZA dissolved in 1 litre of water per plastic bag at a two-week interval.

\section{Procedures \\ Temperature, light intensity, and humidity measurements}

Temperature (minimum and maximum), humidity, and light intensity were recorded daily (from February to December, 2020) both in shading and open field at 8.00 AM, 12.00 $\mathrm{AM}$, and 16.00 PM. 


\section{DNA marker analysis}

Extraction and Purification of DNA (Doyle and Doyle, 1990 with modification): 0,1 gram of young leaf was grinded by PVP 50-80mg (powder) plus $1 \mathrm{ml}$ buffer CTAB (3\%). This samples were transferred to $2 \mathrm{ml}$ tube added by $10 \mu \mathrm{l}$ mercap to ethanol and it was incubated for 30 minutes on $65^{\circ} \mathrm{C}$. The tubes then were added by $1 / 10$ of volume $\mathrm{Na}$-acetate and twice of the volume of chloroform: isoamyl alcohol $(24: 1, \mathrm{v} / \mathrm{v})$. The next step, these tubes were centrifuged on 12,000 rpm for 15 minutes on room temperature. The Supernatants was moved to $1.5 \mathrm{ml}$ tubes that was added with isopropanol and kept in the freezer for 1 hour. After that they were centrifuged on $12,000 \mathrm{rpm}$ for 15 minutes in the room temperature. The pellets were washed by $70 \%$ ethanol then was centrifuged by $12,000 \mathrm{rpm}$ for 15 minutes and were dried in LAF. After drying, the pellets were added with $300 \mu \mathrm{l}$ TE as a buffer plus $2 \mu \mathrm{l}$ RNase, then were incubated on $37^{\circ} \mathrm{C}$ for 30 minutes. $1 / 10$ of volume Na-acetate and $300 \mu \mathrm{l}$ chloroform: isoamyl alcohol $(24: 1, \mathrm{v} / \mathrm{v})$ were added into the tubes, and were added with $1 \mathrm{x}$ volume of $70 \%$ ethanol. These samples then were centrifuged $(12,000 \mathrm{rpm})$ for 15 minutes in room temperature. The pellets were dried in LAF then there were diluted with $100 \mu \mathrm{l}$ buffer TE. DNA quality was analyzed by using spectrophotometer Infinite M Nano based on the ratio of 260 wave length absorbents with 280 wave length. Six Primers (L8, L9, L10, L11, L13, and L22) were used for DNA markers.

PCR-ISSR (Chiang et al., 2010 modification): $2 \mu$ l (50ng) DNA, $10 \mu \mathrm{l}$ taq green PCR 2x Master Mix, $4 \mu \mathrm{l}$ primer, and $4 \mu \mathrm{l}$ water nuclease-free were mixed. Mixed PCR was spin down at $60 \mathrm{rpm}$ for 15-30 seconds, then was put on PCR machine with 40 cycles. Process of PCR analyses consisted of initial denaturation, denaturation, annealing, extension, final extension, and cooling with different temperature and time for each process.

\section{Scoring and dendrogram analyses}

Scoring of DNA band was done based on availability of DNA band on plants. Grouping within dendrogram was analysed with SAHN on NTSys-PC version 2.10 (Rohlf, 1992).

\section{Morphological attributes}

Plant height was measured from the budded position (joined of rootstock and shoot) to the highest point of growth. Stem diameter and rootstock diameter of eighteen - month - old budded seedlings were measured on $5 \mathrm{~cm}$ from above and below of the budded position, respectively. Leaf area was measured with Portable Leaf area meter, whereas dry matter such as leaf dry weight, shoot and root dry weight was measured by weighing these matters after putting on the oven at $60^{\circ} \mathrm{C}$ for 48 hours. Specific leaf area (leaf area/leaf dry weight), percentage of flush growth, and shoot/root ratio were also observed. All measurements were recorded at the end of this study.

\section{Physiological attributes}

Chlorophyll a, b, a-b, a/b, and total Carotene on the leaf analyses was adopted from (Sumanta et al., 2014). Accurately weighted $0.5 \mathrm{~g}$ of fresh plant leaf sample was taken, and homogenized in tissue homogenizer with $10 \mathrm{ml}$ of $95 \%$ ethanol. Homogenised sample mixture was centrifuged for $10,000 \mathrm{rpm}$ for $15 \mathrm{~min}$ at $40^{\circ} \mathrm{C}$. The supernatant was separated and $0.5 \mathrm{ml}$ of it is mixed with $4.5 \mathrm{ml}$ of this solvent. The solution mixture was analysed for Chlorophyll-a, Chlorophyll-b and carotenoids content in spectrophotometer (Parkin). The equation used for the quantification of Chlorophyll-a, Chlorophyll-b, and carotenoids by $95 \%$ ethanol solvents are:

Ch-a $=13.36 \mathrm{~A} 664-5.19$ A 649

Ch-b $=27.43 \mathrm{~A} 649-8.12 \mathrm{~A} 664$

$\mathrm{C} x+\mathrm{c}=(1000 \mathrm{~A} 470-2.13 \mathrm{Ca}-97.63 \mathrm{Cb}) / 209$

$\mathrm{A}=$ Absorbance, $\mathrm{Ch}-\mathrm{a}=$ Chlorophyll $\mathrm{a}, \mathrm{Ch}-\mathrm{b}=$ Chlorophyll b, $C \mathrm{x}+\mathrm{c}=$ Carotenoids (Sumanta et al., 2014).

Stomata density was measured by using clear nail polish to make an impression or cast of the lower side of leaf surface. The cast is removed with sticky tape and placed on a microscope slide. The stomata are viewed under the microscope at 100x magnification in an area of $50 \mu \mathrm{m} x$ $50 \mu \mathrm{m}\left(2,500 \mu \mathrm{m}^{2}\right)$.

\section{Pests and diseases invasion}

Pests and diseases were monitored by randomly inspecting of two plants per treatments within shading and open field condition. Sampling was done monthly to determine the intensity of presence/absence of pests and diseases.

\section{Data analyses}

The data were analysed using the analysis of variance (ANOVA). Contrast orthogonal was also measured for determining contribution of morphological and physiological traits to cultivar classification and clustering as well. A pairwise Jaccard's similarity was also measured to obtain the coefficient among cultivars. For any significant differences between treatments was evaluated by Duncan Multiple Range Test (DMRT) at $\mathrm{p}<0.05$. All data analysis was performed with the Minitab 16 software.

\section{RESULTS AND DISCUSSION}

\section{Temperature, humidity, and light intensity measurements} Temperature in the nursery (shading condition) and open field was different at 8.00 AM and 12.00 AM. The average of temperature in the nursery and open field 
were $30.1^{\circ} \mathrm{C}$ and $27.9^{\circ} \mathrm{C}$, respectively. The nursery also had higher maximum temperature and lower average of humidity, i.e., $47.0 \%$. Moreover, the light intensity in nursery house was $58.6 \%$, it was lower than that of open field one.

\section{Response of morphological attributes}

The highest flush growth percentage (51.11\%) was obtained from citrus seedling K. Madura under open field condition, while rootstock diameter of S. Madu grown in nursery house was the biggest $(17.28 \mathrm{~mm})$ and followed by $\mathrm{K}$. Kacang $(17.07 \mathrm{~mm})$. Moreover, S. Madu grown in open field produced highest root dry weight $(69.29 \mathrm{~g})$ as compared to other cultivars (Table 1).

Budiarto et al. (2019) mentioned that under shading condition, the improvement of most morphological variables of Kaffir lime seedlings growth was occurred within the ranged of $17->200 \%$. Nevertheless, Raveh et al. (2003) reported that shoot and root dry weight growth of young citrus tree were not significantly influenced by shading.

The plant height, shoot diameter, and leaf thickness of citrus budded plants grown in nursery were higher than open field except for shoot dry weight. The best growth among cultivars was Keprok cv. Kacang. It had better value of plant height, shoot diameter, leaf thickness, leaf and shoot dry weight, and shoot/root ratio, while the highest of specific leaf area one was recorded by Keprok cv. Terigas. It was apparently that Keprok cv. Kacang has capability to acclimate properly both under nursery house and open field (Table 2).

These results are consistent with Zhou et al. (2018)'s research on the 'Valencia' orange. The trees grown under shade nets were taller in comparing to the control trees. This finding were also in agreement with the previous findings of Ozturk and Serdar (2016) and Sevillano et al. (2016). The chestnut grown under shade net with decreasing light quantity would have much higher leaf length, diameter, and leaf area as well as their root. For the value of shoot dry weight, it was similar to Sevillano et al. (2016) and Matjaž and Primož (2010) results. The difference response of cultivars particularly within Mandarin group mainly due to phenotypically different individuals (Dorji and Yapwattanaphun, 2011). Likewise, genetically the differences of some species or varieties may also be due to their gene expression. It means that they have a variety of capability to acclimate with certain environmental conditions (Ramanjaneyulu et al., 2017).

Under shading condition, Raveh et al. (2003) revealed that the citrus leaf carbohydrate concentrations significantly increased as consequence the increased vegetative growth. This condition would enhance the accumulation of biomass on the leaf due to light intensity level that may prioritize for height growth, leaf size and leaf weight (Sevillano et al., 2016). The high vegetative growth is usually corresponding to increase of the synthesis of hormones caused by low photon fluency rate, hence let the plants to acclimate the favorably microclimate (Wit et al., 2016). In terms of the shade nets construction, it may induce a conducive air and soil environment around the root system (Abul-Soud et al., 2014). In this study, light intensity under nursery house was $58.6 \%$ that may increase plant height, shoot diameter, and leaf thickness. Light intensity is very important for plant development because it provides energy for photosynthesis, and also serve as signals via light receptors sensitive that is used to regulate plant development. Hence, changes in

Table 1: Response of flush growth, rootstock diameter, and root dry weight to locations

\begin{tabular}{|c|c|c|c|c|}
\hline Location & Cultivar & Flush growth (\%) & Rootstock diameter (mm) & Root dry weight (g) \\
\hline \multirow[t]{7}{*}{ Nursery } & S. Banjar & $22.78 \mathrm{abc}$ & $16.84 \mathrm{abc}$ & $54.94 \mathrm{abc}$ \\
\hline & S. Madu & $20.00 \mathrm{bc}$ & $17.28 \mathrm{a}$ & $49.48 \mathrm{abc}$ \\
\hline & S. Pontianak & $20.56 \mathrm{bc}$ & $16.09 \mathrm{abc}$ & $63.06 \mathrm{ab}$ \\
\hline & K.Terigas & $28.89 a b c$ & $13.40 \mathrm{de}$ & $39.13 \mathrm{c}$ \\
\hline & K. Gayo & $24.44 \mathrm{abc}$ & $15.47 \mathrm{abcd}$ & $58.22 \mathrm{abc}$ \\
\hline & K. Kacang & $18.33 \mathrm{bc}$ & $17.07 \mathrm{ab}$ & $52.26 \mathrm{abc}$ \\
\hline & K. Madura & $28.33 \mathrm{abc}$ & $16.58 \mathrm{abc}$ & $48.38 \mathrm{abc}$ \\
\hline \multirow[t]{7}{*}{ Open Field } & S. Banjar & $37.78 \mathrm{ab}$ & 15.29 abcde & $54.36 \mathrm{abc}$ \\
\hline & S. Madu & $0.00 \mathrm{c}$ & $14.82 \mathrm{cde}$ & 69.29 a \\
\hline & S. Pontianak & $32.22 \mathrm{ab}$ & $15.45 \mathrm{abcd}$ & $61.65 \mathrm{abc}$ \\
\hline & K.Terigas & $4222 \mathrm{ab}$ & 13.33 e & $40.15 \mathrm{bc}$ \\
\hline & K. Gayo & $36.67 \mathrm{ab}$ & $15.89 \mathrm{abc}$ & $57.55 \mathrm{abc}$ \\
\hline & K. Kacang & $43.33 \mathrm{ab}$ & 15.14 bcde & $63.24 \mathrm{ab}$ \\
\hline & K. Madura & $51.11 \mathrm{a}$ & $16.03 \mathrm{abc}$ & $54.01 \mathrm{abc}$ \\
\hline $\mathrm{R}^{2}(\%)$ & & 88.80 & 94.56 & 81.88 \\
\hline
\end{tabular}

Means followed by different alphabets in the same column are significantly different based on DMRT at p<0.05; ns: not significant different at 0.05 level; S: Siam (Tangerine type); K: Keprok (Mandarin type) 
Table 2: Response of plant height, shoot diameter, leaf dry weight, shoot dry weight, specific leaf area, leaf thickness, and shoot/ root ratio to locations

\begin{tabular}{|c|c|c|c|c|c|c|c|}
\hline $\begin{array}{l}\text { Treatment } \\
\text { Treatments }\end{array}$ & $\begin{array}{c}\text { Plant } \\
\text { height }(\mathrm{cm})\end{array}$ & $\begin{array}{c}\text { Shoot } \\
\text { diameter }(\mathrm{mm})\end{array}$ & $\begin{array}{c}\text { Leaf dry } \\
\text { weight (g) }\end{array}$ & $\begin{array}{l}\text { Shoot dry } \\
\text { weight (g) }\end{array}$ & $\begin{array}{l}\text { Specific Leaf } \\
\text { Area }(\mathrm{cm} 2 / \mathrm{g})\end{array}$ & $\begin{array}{l}\text { Leaf thickness } \\
(\mathrm{mm})\end{array}$ & $\begin{array}{c}\text { Shoot/ } \\
\text { Root ratio }\end{array}$ \\
\hline \multicolumn{8}{|l|}{ Location } \\
\hline Nursery house & $104.86 \mathrm{a}$ & 12. $26 \mathrm{a}$ & ns & $113.85 b$ & ns & $0.41 \mathrm{a}$ & ns \\
\hline Open field & $84.43 b$ & $11.18 b$ & ns & $125.44 \mathrm{a}$ & ns & $0.33 b$ & ns \\
\hline \multicolumn{8}{|l|}{ Cultivar } \\
\hline S. Banjar & $101.25 \mathrm{ab}$ & $11.84 a b$ & $0.17 \mathrm{abc}$ & $116.73 \mathrm{bc}$ & $111.67 \mathrm{c}$ & $0.35 a b$ & $2.15 a b$ \\
\hline S. Madu & $95.50 \mathrm{abc}$ & $11.90 a b$ & $0.15 \mathrm{~cd}$ & $126.56 a b$ & $138.56 \mathrm{~b}$ & $0.32 \mathrm{~b}$ & $2.21 a b$ \\
\hline S. Pontianak & $101.25 \mathrm{ab}$ & $11.77 \mathrm{bc}$ & $0.19 a b$ & $130.88 a b$ & $114.68 \mathrm{bc}$ & $0.37 a b$ & $2.12 a b$ \\
\hline K.Terigas & $82.75 c$ & $10.08 \mathrm{c}$ & $0.12 \mathrm{~d}$ & $92.91 \mathrm{c}$ & $181.17 \mathrm{a}$ & $0.40 \mathrm{a}$ & $2.34 a b$ \\
\hline K. Gayo & $78.75 c$ & $11.01 \mathrm{bc}$ & $0.17 \mathrm{abc}$ & $110.29 \mathrm{bc}$ & $96.34 \mathrm{c}$ & $0.37 a b$ & $1.91 \mathrm{~b}$ \\
\hline K. Kacang & $111.00 \mathrm{a}$ & $13.57 \mathrm{a}$ & $0.20 \mathrm{a}$ & $150.57 \mathrm{a}$ & $102.51 \mathrm{c}$ & $0.41 \mathrm{a}$ & $2.61 \mathrm{a}$ \\
\hline K. Madura & $92.00 \mathrm{~b} \mathrm{c}$ & $11.89 a b$ & $0.16 \mathrm{bcd}$ & $109.57 \mathrm{bc}$ & $104.12 \mathrm{c}$ & $0.39 a$ & $2.14 a b$ \\
\hline $\mathrm{R}^{2}(\%)$ & 93.92 & 90.03 & 82.50 & 88.03 & 94.93 & 91.00 & 75.45 \\
\hline
\end{tabular}

Means followed by different alphabets in the same column are significantly different based on DMRT at $p<0.05$; ns: not significant different at 0.05 level; S: Siam (Tangerine type); K: Keprok (Mandarin type)

the light levels may lead to different morphological and physiological responses of citrus cultivars.

\section{Response of physiological attributes}

Among physiological attributes, the stomata density showed significantly responses, whereas chlorophyl a, $\mathrm{b}, \mathrm{a}-\mathrm{b}, \mathrm{a} / \mathrm{b}$, and carotene content as well gave the same responses under two locations. Siam cv. Madu seedlings grown in open field produced the highest stomata density $\left(37.22 / 2,500 \mu \mathrm{m}^{2}\right)$, meanwhile Keprok cv. Gayo grown in open field produced the lowest $\left(15.00 / 2,500 \mu \mathrm{m}^{2}\right)$ (Table 3). Bertolino et al. (2019) stated that different of stomata density performance may be caused by genetic and/or environmental conditions especially light intensity. The shading effects on the vegetative as well as physiological responses are vary, even among cultivars of the same plant, including on the shapes, number, and size of stomata (Stamps, 2009). According to Hong et al. (2018), plants that have dense and small ones could easily adapt to more adverse environmental conditions.

Decreasing of their density could be induced by exposing mature leaves to either high $\mathrm{CO}_{2}$ or low light levels such as in case on transgenic wheat lines of TaEPF1-OE2 and TaEPF1-OE4 cultivated under an uncontrolled condition (Dunn et al., 2019). On the other hands, subjecting chestnut or almost all woody plant to a higher of light intensity condition would also increase the values of their stomatal density (Brown et al., 2014). Moreover, Xu and Zhou (2008) reported that there was significantly negative correlation between stomata density and SLA in grass, whereas, increase of stomata density was correlated to leaf development.

In terms of chlorophyll as well as carotene, our finding is opposite to previous research. Garc1'a-Sa'nchez et al. (2006) reported that chlorophyll of citrus seedlings was
Table 3: Response of stomata density to locations

\begin{tabular}{llc}
\hline Location & Cultivar & Stomata density/2,500 $\boldsymbol{\mu m}^{2}$ \\
\hline Nursery & S. Banjar & $26.78 \mathrm{cde}$ \\
& S. Madu & $28.22 \mathrm{bcd}$ \\
& S. Pontianak & $30.56 \mathrm{ab}$ \\
& K.Terigas & $30.22 \mathrm{abc}$ \\
& K. Gayo & $15.00 \mathrm{e}$ \\
& K. Kacang & $21.56 \mathrm{de}$ \\
Open Field & K. Madura & $21.78 \mathrm{de}$ \\
& S. Banjar & $31.11 \mathrm{ab}$ \\
& S. Madu & $37.22 \mathrm{a}$ \\
K.Terigas & S. Pontianak & $21.78 \mathrm{de}$ \\
& & $26.89 \mathrm{bcd}$ \\
& K. Gayo & $28.44 \mathrm{bcd}$ \\
$\mathrm{R}^{2}(\%)$ & K. Kacang & $30.22 \mathrm{abc}$ \\
& K. Madura & $22.00 \mathrm{cde}$ \\
& & 93.34 \\
\hline
\end{tabular}

*different letters beside means denote significant differences between treatments at $p<0.05$ level; S: Siam (Tangerine type); K: Keprok (Mandarin type)

higher under alumni shading net (50\% shading) than control ones, so did for orange tree (Incesu et al., 2016). Shade netting creates a suitable environment for the synthesis of photosynthetic enzymes, thus it induces the increasing of chlorophyll content per unit leaf area (Manja and Aoun, 2019). Meanwhile, the findings of this study showed that temperature in nursery house $\left(30.1^{\circ} \mathrm{C}\right)$ was relatively higher than in open field $\left(27.9^{\circ} \mathrm{C}\right)$ that may lead to chlorophyll degradation, and it makes chlorophyll as well as carotene content give similar response in both nursery house and open field. Moreover, similar microenvironment or concentration of pigments in the leaves in both locations can also influence the same physiological response.

\section{Pests and diseases invasion}

The presence of insect pests such as aphids (Aphis gossypii) and leaf miner (Phyllocnistis citrella) have only been affected 
by locations, while for diseases was not found in this study. The highest aphid intensity $(8.57 \%)$ and leaf miner (40\%) were found on citrus seedlings grown under nursery house and open field, respectively. Population fluctuation and species of aphis are different depending upon species as well as cultivars of citrus within the same species. Identified aphids on both orange (C. sinensis 'Thomson Navel') and mandarin (C. reticulata 'Blanco') increased from 2 to 5 species (Lebbal and Laamari, 2016); 5 species on Satsuma Mandarin (Yoldaş et al., 2011) and 4 species on grape fruit (Citrus x paradisi Macfad.) (Lebbal, 2018). In addition, Marroqu'in et al. (2004) and Cambra et al. (2000) reported that Clementine mandarin was the most visited compared to sweet orange and other citrus species. It looks like that this pest did not show a preference for orange or tangerine trees (Kavallieratos et al., 2004).

However, our finding was opposite to previous studies. According to Kalaitzaki et al. (2019), the highest population of aphids most probably was subjected to the increased newly flush growth and the shoots remain tender. In open field plants, it seems that the highest of leaf miners may due to greater availability of newly leaf flushes (Table 1). This finding was supported by Ahmed et al. (2013) that this pest was affected by seasons, flushing growth, and temperatures as well as species and varieties.

\section{Citrus cultivars classification}

Based on the DNA markers, citrus cultivars were grouped into two main clusters. The coefficient relationship among these clusters was about $85 \%$. Dorji and Yapwattanaphun (2011) reported that the wider range of this value, the more varied the qualitative character. The first cluster on this was comprising of the four cultivars these were Siam cv. Pontianak, Siam cv. Banjar, Keprok cv. Terigas and Siam cv. Madu, in which Siam cv. Pontianak and Siam cv. Banjar were genetically most similar showing $96 \%$ similarity, while Keprok cv. Terigas and Siam cv. Madu had a similarity level of only $85 \%$. The second one comprised of three cultivars, i.e., Keprok cv. Kacang, Keprok cv. Madura and Keprok cv. Gayo in which Keprok cv. Kacang and Keprok cv. Madura were showing $90 \%$ genetic similarity, while Keprok cv. Gayo and Keprok cv. Madura had a similarity level of only $84 \%$. (Fig. 1). Based on a pairwise Jaccard's similarity, co-efficient among all cultivars of citrus ranged from 0.75 to 0.96 . The maximum similarity of 0.96 was observed between cultivars SP (Siam cv. Pontianak) and SB (Siam cv. Banjar), indicating that they are genetically most similar, whereas $\mathrm{SP}$ and $\mathrm{KG}$ (Keprok cv. Gayo) showed least similarity coefficient of 0.75 . Average similarity across all the cultivars was 0.84 .

Based on results of contrast orthogonal analyses (Table 4), we can compare the percentage of variable factors that affected on grouping the cultivars. It was about $64.70 \%$ of

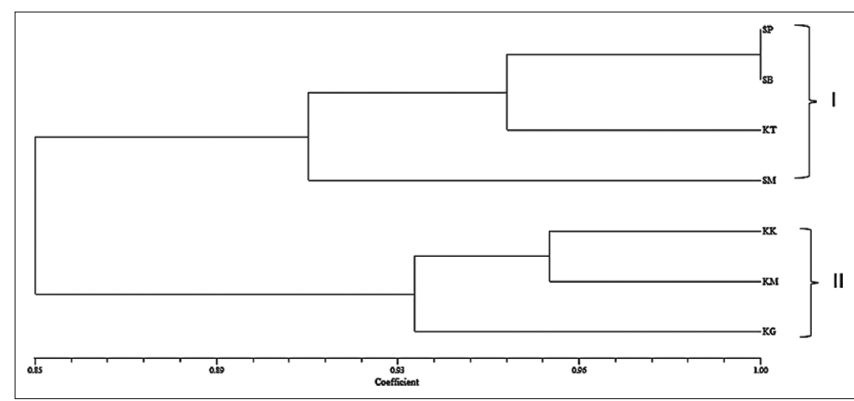

Fig 1. Dendrogram of citrus cultivar relationship. S: Siam (Tangerine type), SP: Siam Pontianak, SB: Siam Banjar, SM: Siam Madu. K: Keprok (Mandarin type), KT: Keprok Terigas, KK: Keprok Kacang, KM: Keprok Madura, KG: Keprok Gayo.

total morphological and physiological variables both under nursery house and open field gave significantly different responses on all cultivars, among of them the specific leaf area (SLA), shoot diameter, and stomata density were more dominant to construct the citrus classification into two split citrus types i.e., cluster I (Siam/Tangerine) and cluster II (Keprok/Mandarin) (Table 4, column Cluster I vs Cluster II).

$\mathrm{KT}$ or Keprok cv. Terigas in Indonesia actually is known as one of Keprok or Mandarin types. However, in our result this cultivar based on the DNA analysis belongs into cluster I or Tangerine group. There was about $47.06 \%$ of traits such as flush growth, leaf area, shoot/ root ratio, chlorophyl (b, a $+\mathrm{b}, \mathrm{a} / \mathrm{b})$, stomata density, and carotene did not significantly different within cluster I: $\mathrm{KT}$ vs SP and SB (Table 4). Hence, they may contribute to classify this cultivar into Tangerine group with three Siam cultivars i.e., Siam cv. Pontianak, Siam cv. Banjar, and Siam cv. Madu. Furthermore, this cultivar also had 52.94\% significantly different responses of all variables observed when it compared with other Keprok/Mandarin members i.e., Keprok cv. Kacang, Keprok cv. Madura and Keprok cv. Gayo; the dominantly ones were plant height, SLA, shoot diameter, rootstock diameter, shoot dry weight, root dry weight, and leaf dry weight. This reason may highly contribute to separate Keprok cv. Terigas from the cluster II or Keprok group (Table 4., column Mandarin Group).

Moreover, the contrast test of morphological and physiological traits of inter group citrus showed that the percentage changes of growth and develop capacity of Keprok/Mandarin group from open field to nursery house conditions increased by $2.35 \%$, whereas for Siam/Tangerine group tended to decrease by $8.96 \%$. Generally, the average of reduction value on all parameters of Keprok type were smaller than Siam one. The variables of flush growth and specific leaf area mostly affected that condition (Table 5).

The results of our research are in line with the other previous ones. Morphological trait-based identification as 
Table 4: Contribution of 17 variables to cultivar grouping

\begin{tabular}{|c|c|c|c|c|c|c|c|}
\hline \multirow[t]{2}{*}{ No } & \multirow[t]{2}{*}{ Variables } & \multicolumn{2}{|c|}{$\begin{array}{l}\text { Cluster I vs Cluster II } \\
\text { Tangerine vs Mandarin }\end{array}$} & \multicolumn{2}{|c|}{$\begin{array}{l}\text { Cluster I: KT vs } \\
\text { SP\&SB }\end{array}$} & \multicolumn{2}{|c|}{$\begin{array}{l}\text { Mandarin Group: KT vs } \\
\text { others mandarins }\end{array}$} \\
\hline & & Nursery & Open field & Nursery & Open field & Nursery & Open field \\
\hline 1 & Plant height & ns & ns & $\star *$ & ** & * & ** \\
\hline 2 & Flush growth & ns & ** & ns & ns & ns & ns \\
\hline 3 & Leaf area & * & ns & ns & ns & * & ns \\
\hline 4 & Specific leaf area & ** & $* *$ & ** & ** & ** & ** \\
\hline 5 & Shoot diameter & $\star \star$ & * & ** & $\star *$ & ** & ** \\
\hline 6 & Leaf thickness & ** & ns & ns & ** & ns & ** \\
\hline 7 & Rootstock diameter & $* *$ & ns & ** & ** & ** & ** \\
\hline 8 & Shoot dry weight & $\star *$ & ns & ** & ** & ** & ** \\
\hline 9 & Root dry weight & ns & ns & ** & ** & ** & ** \\
\hline 10 & Leaf dry weight & ns & ** & ** & ** & ** & ** \\
\hline 11 & Shoot/Root ratio & ns & ns & ns & ns & ns & * \\
\hline 12 & Chlorophyl a & ns & ns & * & ns & ns & ns \\
\hline 13 & Chlorophyl b & ns & ns & ns & ns & ns & ns \\
\hline 14 & Chlorophyl $a+b$ & ns & ns & ns & ns & ns & ns \\
\hline 15 & Chlorophyl a/b & ns & ns & ns & ns & ns & ns \\
\hline 16 & Stomata Density & ** & * & ns & ns & $* *$ & ns \\
\hline 17 & Carotene & ns & ns & ns & ns & ns & ns \\
\hline
\end{tabular}

* within a row only, it significant at the $p<0.05$ level; ** significant at $p<0.01 ; n s=$ non-significant

KT: Keprok Terigas; SP: Siam Pontianak; SB: Siam Banjar; KK: Keprok Kacang; KM: Keprok Madura; KG: Keprok Gayo (Siam = Tangerine; Keprok = Mandarin)

Table 5: The contrast test of the morphological and physiological traits of inter group citrus species

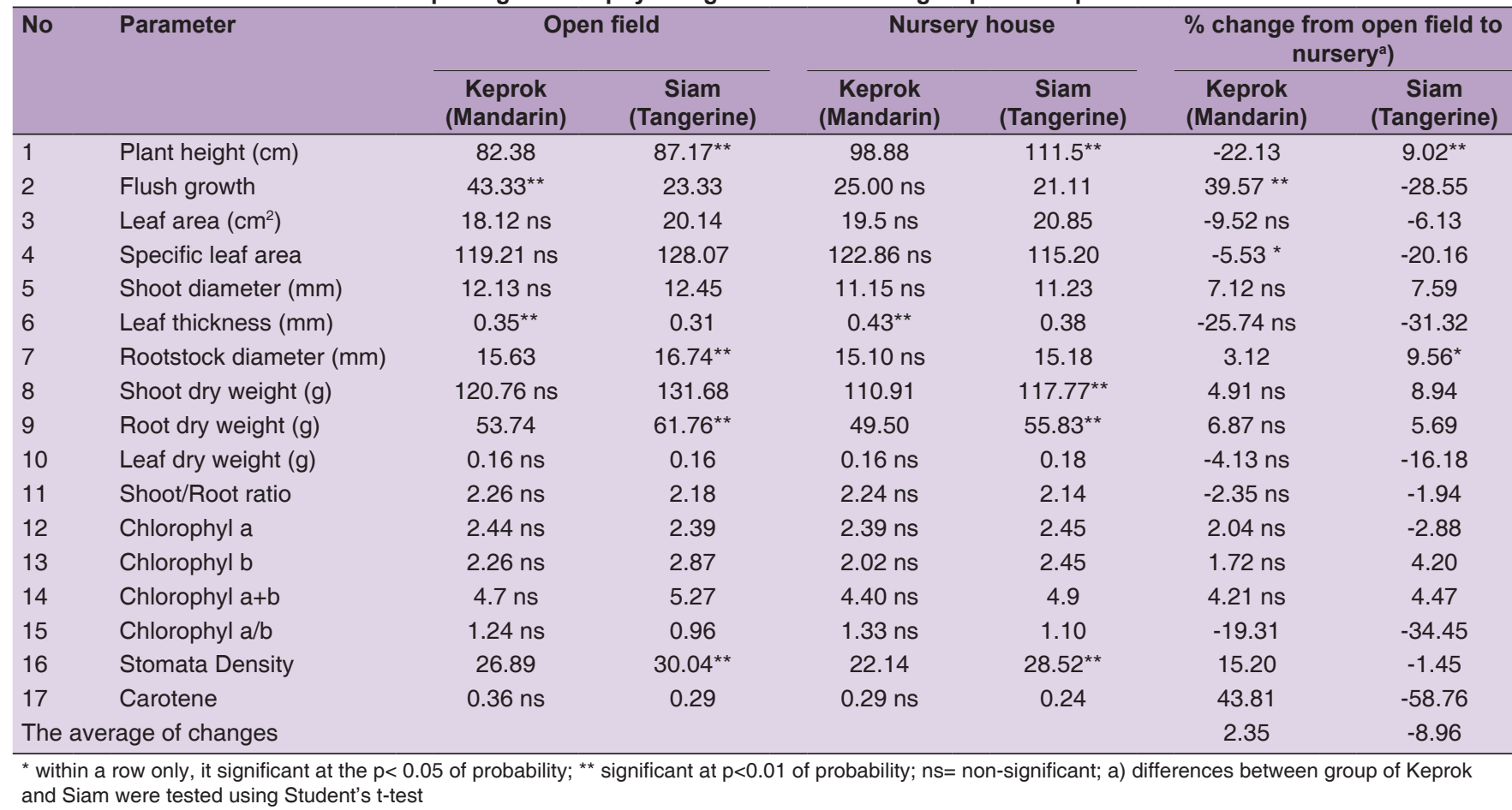

well as physiological ones for diversity or clustering analysis have been successfully used in rice cultivars (Adeyemi et al., 2011), the tolerant or sensitive shading of mungbean classification under shading condition (Sundari, 2009) and variation of peanut varieties (Purnomo and Khotimah, 2019). Furthermore, Penjor et al. (2014) revealed that morphological traits also could be contributed on genetic classification and diversification of limes citrus.

\section{CONCLUSION}

Morphological attributes such as the flush growth percentage, rootstock diameter, and root dry weight of Siam (Tangerine) and Keprok (Mandarin) showed significantly response to locations, whereas for physiological attributes, it was only stomata density that has significantly effect. Siam cv. Madu and Keprok cv. Madura were more sensitive to 
different environmental condition, meanwhile, Keprok cv. Kacang genetically has more tolerant to perform optimally in either nursery house or open field as compared to others. Principally, responses of morphological and physiological traits to locations were varied.

Based on DNA, citrus cultivars were grouped into two major clusters, each of them comprises of three Siam cultivars plus Keprok cv. Terigas, and the other group has the rest of Keprok ones. Contribution of morphological and physiological variable traits to construct the two citrus grouping was about $64.70 \%$. Meanwhile, $52.94 \%$ and $47.06 \%$ of all variable traits respectively contributed to separate the Keprok cv. Terigas from Keprok group, and include it into Siam. The percentage of change in growth and develop capacity of Keprok group from open field to nursery house increased by $2.35 \%$, whereas for Siam tended to decrease by $8.96 \%$. Morphological and physiological traits may also useful for supporting genetically evaluation in identification of citrus cultivars especially for improving citrus breeding programs.

\section{Authors' contribution}

We stated that H, N.F.D., S.S., A.S., M.E.D., and S.W. are main contributors from planned and conducted the experiment, field observation, to wrote the manuscript and critical feedback of manuscript.

\section{REFERENCES}

Adeyemi, R., A. Gana and S. Yusuf. 2011. Biometrical character interrelationship and morphological variations in some upland rice (oryza sativa L.) varieties. Afr. J. Food Agric. Nutr. Dev. 11: 4673-4687.

Agisimanto, D., C. Martasari and A. Supriyanto. 2007. Perbedaan primer RAPD dan ISSR dalam identifikasi hubungan kekerabatan genetik jeruk siam (Citrus suhuniensis L. Tan) Indonesia. J. Hortikult. 17: 101-110.

Ahmed, S., M. A. Khan, B. Hassan, H. Haider and S. F. Ahmad. 2013. Pakistan entomologist studies on citrus leaf miner (CLM) in relation to abiotic factors on different host plants in Punjab, Pakistan. Pak. Entomol. 35(1): 5-10.

Akpo, E., T. Jan, D. K. Kossou, A. O. Omore and P. C. Struik. 2014. Forest ecology and management effects of nursery management practices on morphological quality attributes of tree seedlings at planting: The case of oil palm (Elaeis guineensis Jacq). Forest Ecol. Manage. 324: 28-36.

Barreto, C. V. G., D. Janeiro, R. S. Ferrarezi and R. Testezlaf. 2015. Rangpur lime seedlings irrigated by a prototype subirrigation tray. Hortc Sci. 50: 123-129.

Bertolino, L. T., R. S. Caine, J. E. Gray and J. E. Gray. 2019. Impact of stomatal density and morphology on water-use efficiency in a changing world. Front. Plant Sci. 10: 1-10.

Brown, C. E., M. V. Mickelbart and D. F. Jacobs. 2014. Leaf physiology and biomass allocation of backcross hybrid American chestnut (Castanea dentata) seedlings in response to light and water availability. Tree Physiol. 34: 1362-1375.
Budiarto, R., E. Santosa, D. Efendi and A. Agusta. 2019. Agronomical and physiological characters of kaffir lime (Citrus hystrix DC) seedling under artificial shading and pruning. Emirates J. Food Agric. 31: 222-230.

Cambra, M., M. T. Gorris, C. Marroquín, M. P. Román, A. Olmos, M. C. Martínez, A. H. De Mendoza, A. López and L. Navarro. 2000. Incidence and epidemiology of Citrus tristeza virus in the Valencian community of Spain. Virus Res. 71(1-2): 85-95.

Chiang, K. K., I. C. Wen, W. Y. Lee, C. Y. Chang, A. Chiang, I. C. Wen, W. Y. Lee and C. Y. Chang. 2010. Genetic diversity analysis using ISSR marker on Longan. J. Taiwan Agric. Res. 59: 185-196.

Dorji, K. and C. Yapwattanaphun. 2011. Assessment of morphological diversity of mandarin (Citrus reticulata) accessions in Bhutan. J. Agric. Technol. 7(2): 485-495.

Doyle, J. J. and J. L. Doyle. 1990. Isolation of plant DNA from fresh tissue. Focus, 12: 13-15.

Dunn, J., L. Hunt, M. Afsharinafar, M. A. Meselmani, A. Mitchell, R. Howells, E. Wallington and A. J. Fleming. 2019. Reduced stomatal density in bread wheat leads to increased water-use efficiency. J. Exp. Bot. 70(18): 4737-4747.

García-sánchez, F., I. Simón, V. Lidón, F. J. Manera, S. Simón-Grao, J. G. Pérez-Pérez and V. Gimeno. 2015. Shade screen increases the vegetative growth but not the production in "Fino 49" lemon trees grafted on Citrus macrophylla and Citrus aurantium. Sci. Horticult. 194: 175-180.

Garcıa-Sanchez, F., J. P. Syvertsen, V. Martınez and J. C. Melgar. 2006. Salinity tolerance of "Valencia" orange trees on rootstocks with contrasting salt tolerance is not improved by moderate shade. Sci. Horticult. 194: 175-180.

Haase, D. L. 2008. Understanding forest seedling quality: Measurements and interpretation. Tree Planters Notes. 52: 24-30.

Handl, Z. A. 2016. Response sour orange Citrus aurantium L. Seedlings in a local class proline and sodium chloride in avoid damage to salt stress salt. Int. J. Curr. Microbiol. App. Sci. 5: 1066-1071.

Hong, T., H. Lin and D. He. 2018. Characteristics and correlations of leaf stomata in different Aleurites montana provenances. PLoS One. 13(12):10.

Incesu, M., T. Yeşilog, B. Çimen and B. Yılmaz. 2016. Effects of nursery shading on plant growth, chlorophyll content and PSII in "Lane Late" navel orange seedlings. Acta Hortic. 1130: 301-306.

Kalaitzaki, A., S. Awad, E. Malandraki, P. D. Papapetrou, I. Livieratos and J. T. Margaritopoulos. 2019. Aphid species composition in populations from citrus orchards in a region of the island of Crete. Bull. Insectol. 72: 143-133.

Kavallieratos, N. G., G. J. Stathas and Ž. Tomanović. 2004. Seasonal abundance of parasitoids (Hymenoptera: Braconidae, Aphidiinae) and predators (Coleoptera: Coccinellidae) of aphids infesting citrus in Greece. Biol. Section Zool. 59: 191-196.

Lebbal, S. 2018. Fluctuations of aphid populations on grapefruit (Citrus x paradisi Macfad.). Acta Agric. Sloven. 111(3): 575-580.

Lebbal, S. and M. Laamari. 2016. Population dynamics of aphids (Aphididae) on orange (Citrus sinensis Thomson navel) and Mandarin (Citrus reticulata "Blanco"). Acta Agric. Sloven. 107(1): 137-145.

Li, Z., R. Zhang, S. Xia, L. Wang, C. Liu, R. Zhang, Z. Fan, F. Chen and Y. Liu. 2019. Interactions between N, P and K fertilizers affect the environment and the yield and quality of satsumas. Global Ecol. Conserv. 19: 12.

Abul-Soud, M., M. A. Abdrabbo and A. A. Farag. 2014. Increasing soil organic matter content as a key factor for sustainable increasing 
soil organic matter content as a key factor for sustainable production of sweet pepper. Int. J. Plant Soil Sci. 3(6): 707-723.

Mahmood, A., Y. Hu, J. Tanny and E. A. Asante. 2018. Effects of shading and insect-proof screens on crop microclimate and production: $A$ review of recent advances. Sci. Hortic. 241: 241-251.

Manja, K. and M. Aoun. 2019. The use of nets for tree fruit crops and their impact on the production: A review. Sci. Hortic. 246: 110-122.

Marroquın, C., A. Olmos, M. T. Gorris, E. Bertolini, M. C. Martınez, E. A. Carbonell, A. H. de Mendoza and M. Cambra. 2004. Estimation of the number of aphids carrying Citrus tristeza virus that visit adult citrus trees. Virus Res. 100: 101-108.

Martasari, C. 2012. Characterization of Indonesian "Siam" cultivar (Citrus nobilis Lour.) by morphological and ISSR markers. ARPN J. Agric. Biol. Sci. 7(10): 830-835.

Matjaž, Č. and S. Primož. 2010. Root distribution of under-planted European beech (Fagus sylvatica L.) below the canopy of a mature Norway spruce stand as a function of light. Eur. J. Forest Res. 129(4): 531-539.

Mattos, D. Jr., F. W. R. Hippler, R. M. Boaretto, E. S. Stuchi and J. A. Quaggio. 2017. Soil boron fertilization: The role of nutrient sources and rootstocks in citrus production. J. Integrat. Agric. 16(7): 1609-1616.

Mditshwa, A., L. Samukelo and S. Zeray. 2019. Shade netting on subtropical fruit: Effect on environmental conditions, tree physiology and fruit quality. Sci. Hortic. 256: 10.

Nyoka, B. I., R. Kamanga, J. Njoloma, R. Jamnadass and S. Mng. 2018. Quality of tree seedlings produced in nurseries in Malawi : An assessment of morphological attributes. Qual. Tree Seedlings Prod. Nurs. Malawi . 8028: 1-15.

Ortas, I. and O. Ustuner. 2014. Scientia horticulturae determination of different growth media and various mycorrhizae species on citrus growth and nutrient uptake. Sci. Hortic. 166: 84-90.

Ozturk, A. and U. Serdar. 2016. Effects of different nursery conditions on the plant development and some leaf characteristics in Chestnuts (Castanea sativa Mill.). Aust. J. Crop Sci. 5(10): 1218-1223.

Penjor, T., T. Mimura, R. Matsumoto, M. Yamamoto and Y. Nagano. 2014. Characterization of limes (Citrus aurantifolia) grown in Bhutan and Indonesia using high-throughput sequencing. Sci. Rep. 4: 1-9.

Perumal, M., M. E. Wasli and H. O. S. Ying. 2019. Influences of inorganic and organic fertilizers to morphological quality attributes of Shorea macrophylla seedlings in a tropical nursery. Biodiversitas. 20(8): 2110-2118.

Purnomo, P. and N. Khotimah. 2019. Variations and phenetic analysis of peanut cultivars (Arachis hypogaea L.) Based on morphological characteristics. J. Trop. Biodivers. Biotechnol. 4(1): 24-31.

Ramanjaneyulu, A. V., K. Indudhar Reddy, P. Spandana Bhatt, T. L. Neelima and A. Srinivas. 2017. Influence of pigeonpea varieties, $\mathrm{N}$ levels and planting methods on yield and economics under rainfed conditions. Legume Res. 40(5): 911-915.

Raveh, E., S. Cohen and D. Yakir. 2003. Increased growth of young citrus trees under reduced radiation load in a semi-arid climate. J. Exp. Bot. 54(381): 365-373.

Rohlf, F. J. 1992. Ntsys-Pc, Numerical Taxonomy and Multivariate Analysis System Version 1.80, Applied Biostatistics, Setauket, NY.

Sevillano, I., I. Short, J. Grant and C. O. Reilly. 2016. Forest ecology and management effects of light availability on morphology, growth and biomass allocation of Fagus sylvatica and Quercus robur seedlings. Forest Ecol. Manage. 374: 11-19.

Stamps, R. H. 2009. Use of colored shade netting in horticulture. Hortscience. 44(2): 239-241.

Sumanta, N., C. I. Haque, J. Nishika and R. Suprakash. 2014 Spectrophotometric analysis of chlorophylls and carotenoids from commonly grown fern species by using various extracting solvents. Res. J. Chem. Sci. 4(9): 2231-2606.

Sundari, T. 2009. Morphological and physiological characteristics of shading tolerant and sensitive mungbean genotypes. Hayati J. Biosci. 16(4): 127-134.

Takoutsing, B., A. Degrande, A. Gyau, F. Nkeumoe and A. Tsobeng. 2014. Assessing the quality of seedlings in small-scale nurseries in the highlands of cameroon: The use of growth characteristics and quality thresholds as indicators. Small Scale Forest. 13: 16

Tinyane, P. P. and D. Sivakumar. 2018. Growing "Hass" avocado fruit under di ff erent coloured shade netting improves the marketable yield and a ff ects fruit ripening. Sci. Hortic. 230: 43-49.

De Wit, M., V. C. Galv and C. Fankhauser. 2016. Light-mediated hormonal regulation of plant growth and development. Annu. Rev. Plant Biol. 67: 513-537.

Xu, Z. and G. Zhou. 2008. Responses of leaf stomatal density to water status and its relationship with photosynthesis in a grass. J. Exp. Bot. 59(12): 3317-3325.

Yoldaş, Z., A. Güncan and T. Koçlu. 2011. Seasonal occurrence of aphids and their natural enemies in Satsuma mandarin orchards in Izmir, Turkey. Turk. Entomol. Derg. 35(1): 59-74.

Zhou, K., D. Jerszurki, A. Sadka, L. Shlizerman and S. Rachmilevitch. 2018. Effects of photoselective netting on root growth and development of young grafted orange trees under semi-arid climate. Sci. Hortic. 238: 272-280. 